\title{
Kulturarvspolitik och museiutställningar
}

KJeLl HANSEN

Syftet med denna artikel är att problematisera museernas roll som kunskapsförmedlare i en (sen-)modern värld och att diskutera hur museerna arbetar med att presentera och producera kulturarv. Museiproducenter agerar ofta inom en dekonstruerande diskurs, som ifrågasätter innebörden $i$ kulturarven, medan museikonsumenterna snarare präglas av en kunskapsrealistisk inställning inför kulturhistoriska utställningar. Detta skapar problem i mötet mellan utställning och besökare.

\section{ETT MISSLYCKAT FÖRSÖK}

I mitten av 1990-talet var jag museichef i Helsingborg och fick då idén att göra en utställning som skulle problematisera våra föreställningar om jordbruk och bönder. Detta var en tid då dekonstruktionen fortfarande var högsta mode inom etnologin, och lite av detta sipprade över till oss i museivärlden också. Vår idé var att, i utställningens form, visa upp tre tydligt skilda föreställningar eller diskurser kring dagens svenska jordbruk. Den pedagogiska tanken var att besökarna skulle lämna utställningen med en insikt om att de sätt vi tänker på jordbruk, är starkt influerade av grundläggande kulturella föreställningar.

Utställningen gjordes $\mathrm{i}$ tre avdelningar. Först kom besökaren in i "idyllen": Kaffebordet var dukat, fåglarna sjöng, solen sken, det doftade hö och svensk högsommar som vi lärt känna den genom Astrid Lindgrens berättelser om Bullerbyn. Härifrån leddes besökaren in i "skräckkammarn" där bilden av jordbruket som ett slags Helvetets förgård tonade fram med hårt rationaliserad industriell djurproduktion, besprutning, där luften genljöd av skrämda djurs skrianden och hotfulla moln tornade upp sig på himlen. I utställningens tredje avdelning, "verkligheten", var tanken att besökaren skulle möte en ganska neutral återgivning av de berättelser vi samlat in bland ett antal skånska bönder om hur deras vardagar såg ut. Vi arbetade således med medel som appellerade både till intellekt och känsla och själva var vi ganska nöjda med vad vi åstadkommit. Tyvärr var min kollega och jag nog de enda som var nöjda.

Som utställning betraktad var det vi åstadkommit närapå en katastrof. Den vanliga publikreaktionen kan illustreras som i det följande: ${ }^{1}$ Personerna är en äldre man, sannolikt en far- eller morfar, som besöker utställningen med sitt kanske sexåriga barnbarn. Efter att ha stigit in i utställningen står de ett tag stilla i 
62 "idyllen" och försöker orientera sig. Texterna som ganska tydligt påpekade att detta är en av flera föresällningar om vad det innebär att vara bonde - tycks inte vara till mycket hjälp. Efter ett tag säger mannen att jaha, så här var det på landet förr. Pojken säger inget. Kanske letar han efter kossor eller hölass. Tjugo sekunder senare är paret på väg in i nästa avdelning. Det tar knappt tio sekunder till de är ute i "verkligheten". Och det är ju klart: Vad ska man egentligen säga, ställd inför dessa skräckbilder, till en sexåring som kanske tycker om både ägg och kyckling? Inte heller utställningens tredje del tycktes ge vare sig vuxen eller barn några uppslag till tal. Hastigt lämnar de utställningslokalen medan den vuxne med större hopp i rösten säger att $n u$ ska vi gå och titta på båtarna

Denna reaktion var ganska typisk för en stor del av besökarna. Vad vi, som utställningsproducenter, ville, var att lyfta fram hur våra nutida bilder av och föreställningar om bönder och jordbruk var konstruerade med hjälp av ett antal stereotyper. Men när vi öppnade utställningen med en idylliserad bild av livet på landet, var det inte sådana tankar vi satte i rörelse, utan snarare en resa i tiden, kanske inte så långt, men i alla fall till 1950-talet och detta räckte för att aktivera en annan förståelsehorisont än den vi hade tänkt oss. De flesta besökare tycktes vara medvetna om att livet som bonde i 1990-talets Skåne knappast omfattade mysiga kaffepauser i bersån, men var däremot ganska fasta i sin övertygelse att kulturhistoriska utställningar tillhör en realistisk genre, alltså att de, om de inte beskriver något som är, med största säkerhet beskriver något som har varit. Trots vår ambition att göra något annat, tycktes utställningen som en genre med fokus på att skildra tid vara så starkt rotad hos besökarna att den tillintetgjorde vårt försök att relativisera. ${ }^{2}$
Syftet med denna artikel är dels att problematisera museernas roll som kunskapsförmedlare i en (sen-)modern värld, dels att diskutera hur museerna arbetar med att presentera och därmed också producera - kulturarv. Det hävdas allmänt (se t.ex. Kirschenblatt-Gimblett 1998, Bohman \& Palmqvist 1997) att museerna genom det institutionaliserade tolkningsföreträde de har, inte bara presenterar utan också skapar kulturarv genom att lyfta ting och företeelser in i det sammanhang som en museiutställning utgör. Museerna formar en bestämd bild av det förgångna och kan därmed sägas vara en politisk institution. Denna position har dock under senare år problematiserats, framför allt genom att museitjänstemännen (antikvarierna) uppmärksammat förekomsten av flera, parallella kulturarv - de fattigas, kvinnornas, arbetarklassens, industrisamhällets, invandrarnas, regionernas, för att bara nämna några (se t.ex. Klein 1997, Silvén 2000, SOU 1999: 18). Denna process kan ses som ett uttryck för hur kulturarvsbegreppet dekonstruerats och är ett resultat av att olika falanger inom museivärlden stridit om inflytandet över betydelseproduktionen den som uppstår när man bestämmer form och innehåll i en utställning. Den utställning vi skapade i Helsingborg var et tydligt exempel på en sådan dekonstruktion av den tidigare entydiga berättelsen om bondelivet, och ett försök att skapa andra förståelsehorisonter. Problemet var emellertid att betydelsekonsumtionen inte befann sig inom den diskurs där vi skapat utställningen. Utställningen blev därmed ett slags sammanbrott i kommunikationen. ${ }^{3}$ I det följande ska jag närmare diskutera den särskilda form för kommunikation som en museiutställning utgör och de konsekvenser detta får när museimännen vill förändra mediet. 


\section{KULTURARVET SOM TID OCH PLATS}

Tid och realism är två helt centrala byggstenar när museerna presenterar kulturarv. Detta, att visa upp kulturarv, är kanske den mest väsentliga delen av vad museerna faktiskt gör i vårt samhälle - om det tycks de flesta vara överens. Däremot kan det råda olika uppfattningar kring i vilken grad museerna, genom urval och presentationsformer, aktivt skapar kulturarv eller om de helt enkelt är institutioner som förmedlar ett historiskt arv som i högre eller lägre grad fallit i glömska. ${ }^{4}$

Begreppet kulturarv förekom första gången vid de kulturhistoriska föreläsningar Victor Rydberg höll i Stockholm 1887. Enligt Svenska Akademins Ordbok skulle med kulturarv förstås: "Vad ett folk o.d. i fråga om (andlig) kultur övertagit från tidigare generationer". Begreppet föll i glömska men fick en renässans under senare delen av 1980-talet. Några avgörande omtolkningar har begreppet dock inte genomgått under de hundra åren det funnits, utan kulturarv anses fortfarande generellt omfatta materiella och andliga uttryck för en grupps/ett folks delade värdesystem, ofta med tillägget att kulturarv har speciella symbolvärden (se t.ex. Bohman 1997). Här finns alltså en stark och levande realistisk praktik som ser uttrycken för kulturarv som överlevare genom tiden.

Kulturarv är ett begrepp som understryker kulturell kontinuitet och det är därmed ingen tillfällighet att såväl arkiv som bibliotek och museer ofta beskrivs med metaforen "vårt kollektiva minne". Är det något vi glömt, slarvat bort eller tappat har vi alltså möjlighet att söka upp något av våra gemensamma minnen och hoppas på att den saknade eller bortglömda informationen eller saken skall finnas bevarad där. Men som med alla minnesfunktioner sker en selektion, så även vid institutionerna. Någon beslutar vad som skall sparas för längre tid, kanske till och med för evigt, och vad som kan undvaras, dvs. kastas och förstöras. Denne någon innehar därmed en maktposition som är avgörande för vilken kunskap som skall finnas att tillgå vid ett studium av det samhälle vari informationen har sitt ursprung eller de omständigheter, dvs. idéer, åsikter, ideologier och kunskaper som frambringat densamma.

Osäkerheten om vad som bör ingå i kulturarvet inbegriper att detta långt ifrån är givet. Exempelvis kan vi tolka hur de kulturpolitiska målens praktiska sätt att förhålla sig till kulturarvet - att bevara och bruka det - dels innebär att ett speciellt perspektiv anläggs på verkligheten, den materiella och immateriella, dels en öppenhet som lämnar fältet fritt för strider om tolkningsföreträden på det professionella musei- och kulturmiljöfältet. Perspektivet är till sin karaktär instrumentellt, vilket innebär att när ett kulturarvsperspektiv anläggs på en företeelse händer det något med den. Den som anlägger perspektivet vill något alldeles särskilt. I första hand det mest konkreta, att bevara. Men minst lika viktigt är viljan att relatera företeelsen till en historia, ett förlopp, en händelse eller kanske en person. Valet av vad som bör ingå i kulturarvet är således beroende av vilken historia den som väljer anser relevant och viktig att berätta. Av detta följer också att det knappast går att tala om ett enda Kulturarv utan om många som ständigt är stadda i förändring. Liksom ett lands, en regions eller en stads historia kan skrivas olika, beroende på vem som för pennan, skiftar kulturarven beroende på vem som definierar eller konstruerar dem. Sker definitionen t.ex. från ett genusperspektiv blir resultatet ett annat än om ett etniskt perspektiv anläggs.

Kulturarvet inbegriper med andra ord ingen 
för alltid fastställd substans utan är resultatet av val som utförs av olika aktörer. Vissa företeelser tycks inneha en permanent plats i kulturarvet, andra ingår under kortare perioder. De företeelser som kan sägas ingå i kulturarvet garanteras heller ingen speciell tolkning. Det räcker alltså inte att som museum samla, vårda och visa. Kulturarvet kan inte presenteras som en fast och oföränderlig materia. I den officiella synen liksom i den syn som framtonar hos de flesta museimän ${ }^{5}$ är bildning och kunskapsöverföring viktiga delar av kulturarvsinstitutionernas publika verksamheter. Samtidigt har det vuxit fram en uppfattning om att det behövs öppna redovisningar av vilka perspektiv som anläggs, vilka alternativa tolkningar som kan tänkas och vilka val som har gjorts. En sådan redovisning kan ske i olika former men bör ha som målsättning att engagera även den enskilde besökaren i tolkningsprocessen. Syftet blir att visa att ingen historia är fastlagd en gång för alla och att den skiftar beroende på vem historieberättaren är och från vilken utsiktspunkt han eller hon blickar ut.

Vi skulle kunna säga att detta är en diskurs som råder kring museipraktiken. Problemet är att den omsvängning som skett i museimannakåren (ännu) inte är förankrad i besökarnas förväntningar. Resultatet kan då lätt bli som i det inledande exemplet, ett sammanbrott i utställningens funktion som kommunicerande medium. Jag skulle vilja hävda att hela den dekonstruktionistiska trend, som skapat intresset för ett mer mångfacetterat kulturarvsbegrepp, blir problematisk när den konfronteras med de konkreta ting och andra uttryck som en utställning byggs av och som besökare lärts att uppfatta som kunskapsrealistiska spår av det förgångna. Eftersom museerna sedan de tillkom varit apparater just för att tydliggöra tiden och det geografiska rummet (jfr Ben- nett1995, Hooper-Greenhill 1992), är det självklart att det är denna typ av problematiseringar som besökarna förväntar sig. Museerna har lärt sina besökare att förvänta sig utställningar som visar att verkligheten förändrats över tid och mellan platser, men inte att ifrågasätta verklighetens realistiska karaktär. I museiutställningar uppfattas gärna ting precis som det de utges för att vara. Idyllen må vara försvunnen, men visas den upp är det ett tecken på att den i alla fall har funnits någon gång någon stans.

En utställning är således något som händer i mötet med besökarna. Snarare än att undersöka vad museerna är eller sägs vara och hur de definierar sig i relation till kulturarvet, kan det därför vara en poäng att se dem som något som sker. Detta innebär att det är utställningarna, snarare än det motiverande och legitimerande tal som omger dem, som avgör hur museerna identifierar sig själva i förhållande till kulturarvet och därmed också hur de i sina vardagliga göromål definierar kulturarv. Diskurser, i form av programmatiska uttalanden och tjänstemäns medvetande om sina roller och uppgifter, kan därmed betraktas som närvarande betingelser som underlättar, försvårar eller förhindrar handlande, men det är den materialiserade handlingen - hur de utställda tingen väljs ut och arrangeras - som är avgörande för utställningarnas funktion i förhållande till besökarna. ${ }^{6}$

\section{KRIGET SOM KULTURARV}

Armémuseum är inrymt i f.d. Stora Tyghuset, Artillerigården, belägen mellan Östermalmstorg och Nybroplan i centrala Stockholm. Jag går in genom porten från Riddargatan och över en stor, öppen, stenlagd plats, som vid 
mitt besök är snötäckt och tom men badar i februarisolens ljus. Här, tänker jag, borde ha sjudit av militärt liv och ljud. Platsen var en gång gjord för det. Men nu är den tom, bara längst bort, vid ingången till museet, står en kvinna med ansiktet vänt mot den svaga solen. Framför museibyggnaden ligger några rader av kanonrör. En skylt påpekar risken för att man kan klämma sig. Väl inne betalar jag mitt inträde, hänger av mig kläderna i garderoben och gör det nästan rituellt obligatoriska toalettbesöket. ${ }^{7}$

På nedre botten öppnar sig den stora salen, fylld av kanoner av olika slag. De egentliga utställningarna ligger på våningarna ovanför. Armémuseum är intressant inte minst därför att museet i samband med en ombyggnad under senare delen av 1990-talet öppnade helt nya s.k. basutställningar år 2000. Här har man ändrat fokus, från "kungar, generaler, och stora segrar till dem som närmast berörts av krig och krigsmakt, d.v.s. soldaterna och deras familjer", som det uttrycks i museets egen informationsbroschyr. Uppenbarligen har avsikten varit att förändra vår syn på kriget, fast någon närmare motivering till detta val ges inte, vare sig $\mathrm{i}$ informationsbroschyren eller i utställningen.

Basutställningen är kronologisk och börjar på plan 3 med vikingarna och fortsätter med medeltid, stormaktstid, karolinsk tid, napoleonskrig fram till sekelskiftet 1900. På plan 2 fortsätter utställningen med perioden 1901 nutid. Medan jag rör mig genom utställningslokalerna funderar jag lite över vad det kan betyda att tusen års historia - omfattande bl.a. de svenska militära försöken på att bli en europeisk stormakt - har inrymts på en yta som bara är det dubbla ${ }^{8}$ mot de senaste hundra, mycket fredliga (i alla fall i ett svenskt perspektiv) åren. Något uppenbart svar finner jag inte. Kanske är det en idé om att besökarna

har lättare att förhålla sig till det som är nära? Eller är det kanske bara för att samlingarna har en sådan karaktär?

Armémuseum har givit nytt liv åt de klassiska dioramorna. På många ställen i utställningen har man skapat små miljöer, med realistiskt utformade dockor i naturlig storlek inplacerade i mer eller mindre dramatiska situationer. Det kan vara en adelsman från senare delen av 1600-talet, placerad på en stol invid ett bord på vilket det ligger ritningar och står ett glas vin. Genom den vidhängande texten får vi veta att denna man antagligen har tyskt ursprung, att han plundrat till sig en förmögenhet under trettioåriga kriget och att han dessutom belönats med jordegendomar för sina insatser för kungen. Utslagen i mannens panna, berättar texten vidare, är typiska symptom på syfilis. Jag hajar till lite och tittar närmare på vaxfiguren - och, jo, där finns några utslag tydligt skulpterade av en skicklig museitekniker. På väggen mitt emot denna installation sitter en text som redogör för göticismens nationscentrerade världsbild. Av sammanhanget kan vi förstå att dessa två företeelser inte bara är samtida, utan också på något sätt är förbundna med varandra.

Lite längre fram i utställningen finns en avdelning med titeln "karolinsk kollaps" som beskriver slutet för det svenska stormaktsväldet. Medan vi tidigare i utställningen mött stiliga uniformer, eleganta vapen och militär uppfinningsrikedom, möter vi här framför allt ihjälfrusna soldater, ${ }^{9}$ sjukdomar, skador och amputationer.

Och så fortsätter utställningen. Där jag går omkring i mina egna tankar talar utställningen ett ganska entydigt språk till mig. I mötet med mig framstår inte tolkningsmöjligheterna som så mångfaldiga: Det är tusen år av svensk 
historia betraktad med krigsmakten och konsten som utgångspunkt. Men det är inte en hjältehistoria man velat berätta, utan snarare en social historia. En berättelse där utställningsmakarna velat förmedla kriget som levd vardag. Där soldater skadas och dör, där sjukdomar härjar, men också karriärer skapas. Det förgångna, som brukade ha en aura av förlorad storhet, har nu blivit något annat eftersom det knappast är möjligt för en nutida statlig svensk institution att hylla kriget - inte ens det förgångna kriget. ${ }^{10}$ I stället har man försökt göra kriget till ett slags lärostycke. Men eftersom offentliga museer knappast får ägna sig åt att moralisera, handlar det didaktiska syftet snarast om att på ett grundläggande, och i själva verket tämligen konkret och bokstavligt sätt visa att krig är smutsiga. När kriget görs till kulturarv i den nya utställningen på Armémuseum är det som ett ganska problematiskt fenomen snarare än som ett odelat gott som vi kan vara stolta över.

Till synes är utställningen förankrad i det historiska förloppet. Hela vägen finns tydliga angivelser av tider, regenter, platser, vänner och fiender. Men samtidigt skapar detta hos en besökare som inte tydligt har internaliserat (krigs)historien en ganska motsatt effekt: den ena händelsen glider över i nästa, jag går surr i århundradena och historien blir en enda massa av enstaka ögonblicksbilder. Bara i enstaka fall händer det något mellan utställningen och mig som besökare.

Medan jag driver omkring hinns jag upp av först en, och sedan ytterligare en grupp av tidigt tonåriga skolelever som guidas runt i utställningen av var sina guider. Medan jag lyssnar till respektive guide - vilket är svårt att undvika om man inte lämnar lokalen - får jag demonstrerat för mig att utställningen minsann inte var lika entydig som jag föreställt mig. Den första guiden har ett tydligt vapentekniskt intresse. Han stannar vid montrar och installerade dioramor och fokuserar på de vapen som visas och berättar sedan länge och gärna om kaliber och effekt, om vapnens taktiska för- och nackdelar och om deras plats i teknikhistorien. Strax efter kommer guide och grupp nummer två. Han stannar sin grupp vid samma montrar och talar lika gärna och lika länge - men denna gång nämns vapnen inte alls. I stället får jag höra hur han förklarar vad en stormakt behövde i fråga om varor och förnödenheter och hur man skaffade sig tillgång till detta. För att tydliggöra för eleverna gör guiden jämförelser mellan då och nu.

Det som utmärker en museiutställning, det materiellt konkreta och därmed till synes ovedersägliga och entydiga, visar sig plötsligt innehålla helt olika möjligheter att plocka fram detaljer och göra sina egna tolkningar - även inom ramen för institutionens egen verksamhet. Kulturarvet har blivit något som kan användas av många olika grupperingar, i olika positioner och med olika mål och syften. Även om det uttalade syftet nog i de flesta fall är att belysa det förgångna finns det också alltid mål i det närvarande, här uttryckt genom hur guiderna vill rikta elevernas blickar åt ett bestämt håll.

\section{POLITIK FÖRKLÄDD TILL KULTURARV}

Som problemområde har kulturarvet under senare år dragit till sig stor uppmärksamhet såväl inom universitetsforskningen som inom museisektorn. För drygt tio år sedan lanserades kulturen som en viktig utvecklingsfaktor för regioner och lokalsamhällen (se t.ex. Lindeborg 1991), en tes som idag är starkt ifrågasatt. Senare har i stället begrepp som särart, 
identitet och annorlundahet blivit viktiga i många gruppers försök att beskriva sig själva i en värld som allt mer präglas av snabba förändringar och transnationella förbindelser. I den bild av världen som målas upp, ges rörlighet, upplösning och instabilitet en central plats. Samtidigt har detta, inte minst på museerna, lett till ett ökat intresse för tillhörighet i tid och rum och ett ökande, eller återvändande, intresse för just kulturarv. Kulturarvet har därmed kommit att allt mer bli en dynamisk grund för politiskt och ekonomiskt handlande. Detta är en av innebörderna av den kulturella mobilisering av det förflutna som idag äger rum (jfr Frykman 2000).

För museerna, som vid första anblicken kanske skulle kunna uppfattas som varande på sin mammas bakgård i det här avseendet, är dock kulturarvshanteringen ganska infekterad. När man på museerna arbetar med gestaltning, arbetar man med relationen mellan de fysiska objekt som finns på museet och de reaktioner man vill att de ska väcka hos besökarna.

Oftast arbetar man då med utgångspunkt i de sinnesintryck, som når besökarna via synen. Från 1600-talets kuriosasamlingar och framåt i tiden är det "blicken" som förenat besökare och föremål. ${ }^{11}$ Samtidigt har den mångfald som föremålen i själva verket utgjort, tonats ned genom att underordnas utställningens berättande budskap (jfr Hetherington 1999, Kirschenblatt-Gimblett 1998). Ett sätt att beskriva museernas dilemma här, är att gripa till den åtskillnad mellan museet som tempel respektive museet som forum eller arena, som museimannen Duncan Cameron framfört (Cameron 1972). Hans val av kategoriterminologi avslöjar väl också att Cameron själv anser att museerna som tempel, dvs. som förvaltare och bevarare av en given uppsättning föremål och kunskaper som tillsam- mans kan sägas utgöra kulturarvet, inte är eftersträvansvärt. I stället bör museerna, menar Cameron numera i likhet med de flesta museimän i Sverige, som fora aktivt delta i den pågående samhällsdebatten. ${ }^{12}$ Museerna bör kunna uttala sig om allt från stenåldersmänniskornas kosthåll (och gärna i relation till dagens dietistiska debatter), via jordbruk, folkdans och sekelskiftets borgerskap till dagens frågor kring mångkultur och genus. Uppfattningen att museet bör vara ett forum innebär att den historia som presenteras inte kan framstå som avslutad och färdigtolkad. För att kunna utgöra ett inlägg i, eller vara en utgångspunkt för, en aktuell samhällsdebatt måste utställningens ämne vara möjligt att tolka på nya sätt. Kanske är det detta som fått antikvarierna på Armémuseum att vilja orientera sig bort från den klassiska militärhistoriska beskrivningen i riktning mot en mer socialhistorisk. Oavsett kan det tydliga valet av nyorientering inte förstås som annat än resultatet av en sannolikt omfattande intern diskussion. Att gå från militärhistoria till socialhistoria kan knappast betraktas som en given väg för det statliga svenska militärhistoriska museet. Den konkreta utställning, som möter besökaren ingår därmed också i ett slags intern, interkontextuell argumentation (jfr Shotter 1993). För den insatte blir varje del i den nya utställning en slags mottext i förhållande till en annan möjlig (tidigare) tolkning. Den nya kontext som den nuvarande utställningen utgör, refererar tyst till och argumenterar emot den kontext för föremålen som en mer traditionell militärhistorisk utställning skulle ge. För den insatte besökaren är denna dolda argumentation antagligen inte så dold. Frågan är hur det är för oss andra, vi som inte omedelbart upplever de argument som finns som en nödvändig, men outtalad förutsättning för det som 
faktiskt berättas. För oss blir den version som nu erbjuds lika avslutad som den som fanns på museet för tjugo år sedan.

Varje utställning försöker ge sitt bidrag till besökarnas bildning, den har ett budskap, en historia den vill berätta. Mycket tyder på att idén om att museet ska vara ett forum snarare än ett tempel inneburit att utställningen som genre tagit steget från en (själv)medveten monolog till en tänkt och önskad dialog. Besökaren förväntas ta aktiv ställning, reflektera och fylla i - kanske t.o.m. argumentera emot - den historia utställningen föreslår. Besökaren betraktas inte längre som en passiv mottagare av budskapet, utan som en aktiv medskapare av kunskap och förståelse. Det finns ingen Absolut Sanning. Denna utveckling är helt i linje med de pedagogiska nyorienteringar som skett från grundskola till universitet, som alla allt mer präglas av olika typer av forskande arbetssätt. Men en utställning är knappast något bra läromedel - oavsett hur den utformas. Normalt stannar en besökare inte längre än 20 - 40 sekunder på samma ställe, han eller hon undviker att läsa texter och intresset avtar ju närmare utgången man kommer (jfr Hein 1999, Hooper-Greenhill 1995). Det är alltså knappast genom den direkta påverkan och budskap som varje enskild utställning förmedlar, som museerna kan sägas ha inflytande. Än mindre kan man förvänta sig att den individuella besökaren aktivt för en dialog med utställningen. ${ }^{13}$ Men även om den enstaka utställningen kanske inte har det genomslag producenterna drömt om, betyder detta inte att utställningen ska ses som betydelselös när det gäller att förmedla budskap. Genom sina utställningar deltar museerna i samhällets offentliga samtal och är därigenom med och formar den samhälleliga bilden av vår historia och vår kultur. Det är här som museernas samhällsroll ligger: i att hjälpa till att ordna naturen, historien, samhället och därmed att strukturera hur människor tänker kring detta. På så sätt har såväl den misslyckade utställningen i Helsingborg, som den avsevärt mer lyckade på Armémuseum varit med om att förändra hur samhället betraktar sina kulturarv.

\section{Gestaltningens PROBLEM}

Idéerna om att kulturarv är beroende av urval, och i slutändan kan betraktas som en kulturell konstruktion, har ett givet ursprung i historikern Eric Hobsbawms diskussion kring hur traditioner kan betraktas som "uppfinningar" tillkomna långt efter den tid de refererar till (Hobsbawm 1983). Kulturarvet är således inte något som har tappats bort och sedan återfunnits, det är i stället resultatet av aktiva processer i nuet. Trots en omfattande diskurs kring bevarande, restaurering, återupptäckt, återskapande, återupplivande, så skapar kulturarvet något nytt i sin samtid, något nytt som samtidigt har bäring på det förflutna.

I litteraturen finns också, framför allt i samband med analyser av museernas framväxt, övertygande argumenteringar för att museerna kan betraktas som barn av nationalismen (se t.ex. Bennett 1995, Bohman 1997a, Hooper-Greenhill 1989, Hylland Eriksen 1996, Karlsson 1998, Leech 1997, Stoklund 1993, 2001). Här finns det dock ytterligare problematiseringar att göra. En sådan kan göras utifrån det faktum att allt fler grupper nu gör anspråk på att allt större delar av det förgångna bör ses som kulturarv, och att det förgångna sträcker sig allt längre in i vår egen tid (se t.ex. Silvén-Garnert 1997).

Museer, till skillnad från de flesta andra kunskapsproducerande och -gestaltande institu- 
tioner, arbetar med att levandegöra kulturarvet genom närhet och koppling till konkreta föremål. Tingen är absolut nödvändiga för att museet ska kunna berätta något. Varje föremål eller företeelse som man vill ställa ut är samtidigt både unik och individuell och generell och allmängiltig. En viktig poäng i den här diskussionen är att gestaltandet handlar om att handskas med museiföremål, som ju, per definition, är viktiga att bevara så intakta och oförvanskade som möjligt. Föremålet är ett dokument, unikt och individuellt, och blir just därigenom ett representativt och användbart exempel på historia, alltså en del av kulturarvet. Det är som en verklig rest ur det förgångna föremålet kommer till oss. Varje föremål är också ett personhistoriskt dokument och därmed en materialisering av ett bestämt levnadsöde. I gestaltningen av detta blir det viktigt att söka återskapa känslan av det biografiskt autentiska och uniciteten knyts då inte till "föremålskroppen" - föremålet som materiellt ting - utan till de människokroppar som använt det och de materiella sammanhang de ingick i. I denna mening ligger föremålets autenticitet inte förborgat $\mathrm{i}$ dess materialitet, utan $\mathrm{i}$ den kontext vi hämtat det ur.

Båda dessa principer används i avgöranden kring hur gestaltningen, utställandet, ska ske. Men gestaltningen kan också diskuteras med hjälp av en annan dikotomi. Vi kan välja att arbeta med en "dokumentarisk historia" för att markera just den individuella och specifika historik som är knuten till föremålet och dess ägare eller brukare. ${ }^{14}$ Detta är en gestaltning som fokuserar på föremålets självt och dess proveniens och som visar inåt mot det unika och särskiljande. Denna gestaltningsform förknippas oftast med idén om museet som tempel. Men vi kan lika gärna välja en "gestaltande historia", som i stället lyfter fram den generella samhällsberättelse som kan knytas till tinget. Detta blir en framställning, som tar fasta på det som binder samman det konkreta med det generella. Här blir historia viktigt och föremålet främst en illustration till ett resonemang som är förankrat någon annanstans. Till detta kommer ytterligare ett dilemma i gestaltningen. Varje utställning rör sig mellan två poler, som vanligtvis drar åt vart sitt håll: $\AA$ ena sidan en strävan efter att försöka återskapa den levda verkligheten, så som den tedde sig för de som levde den, och å andra sidan en vilja att försöka överbrygga tidsspannet och underlätta vår tids förståelse av det förgångna.

I museimännens professionella legitimitet spelar detaljkunskaperna en viktig roll. Ibland kan man få intryck av att museimannen främst ser sig själv som en gränsvakt, som ivrigt bevakar åtskillnaden mellan det sanna och det falska - den sanna autenticiteten definieras som trohet mot detaljerna. I museernas presentationer blir då kontextualisering det samma som att föremålen placeras in i ett korrekt historiskt sammanhang. Men därmed klipps ofta banden till våra samtida levda erfarenheter. Det är här vi finner grunden till den "gäspandets kultur" som griper så många museibesökare. Vi vandrar från monter till monter, från miljö till miljö med en ständigt växande känsla att vi inte riktigt lever upp till idealen. Vi vet att detta borde vara intressant. Att detta borde beröra oss eftersom det handlar om vårt förgångna (eller någon annans förgångna som skulle kunna berätta något väsentligt om oss själva). Men vi grips av trötthet. Blicken irrar, fastnar i detaljer som det inte är meningen att vi ska märka ...

Avståndet är för stort - och det finns inga broar som kan överbrygga det. I museivärlden är man naturligtvis medveten om det här problemet. Men det betraktas i huvudsak som ett 
pedagogiskt problem, som skulle kunna lösas bara man kom på den optimala förmedlingstekniken. Om vi däremot ser det som ett existentiellt problem, borde kravet vara att kulturarvet måste göras relevant för våra samtida erfarenheter. Den stora utmaningen för kulturarvsbranschen ligger därmed i att kunna förena det historiska med det genealogiska, ${ }^{15} \mathrm{i}$ att kunna behålla ett historiskt perspektiv där kulturarvet kan förstås utifrån sitt eget samtida sammanhang samtidigt som vi kan lyckas med att göra det till ett redskap för att bearbeta nutida levda erfarenheter.

Om vi ser bilden av verkligheten inte som något en gång för alla givet och oproblematiskt, kan vi också se hur museerna deltar i den sociala och kulturella konstruktionen av verkligheten. Museernas utställningar bidrar till att producera uppfattningar om hur världen egentligen är beskaffad - om kriget är hjältedåd eller nöd och död. I dag finns - tvärt emot den mer traditionella museimannarollen - hos många av dem som arbetar vid kulturinstitutionerna en känsla av obehag kopplad till rollen som tillrättaläggande historieberättare. Och här ligger en av orsakerna till att många numera hellre vill betrakta sig som tillhandahållare av ett material som brukarna själva får använda sig av och sätta samman så gott de kan. Museimän har på många håll omdefinierat sin roll från att vara historieberättare till att bli skötare av databaser. Det finns en tvekan inför ansvaret att göra tolkningar för andra människor. I stället vill museimän gärna arbeta med att problematisera och ifrågasätta föreställningar om det förgångna och därmed ge besökarna bättre möjligheter att själva tolka. Denna tydliga post-moderna position gör det naturligtvis både omöjligt och orimligt att upprätthålla föreställningen om ett samlat och samlande nationellt kulturarv. Begreppet har då också genomgått en kraftig metamorfos under senare år, vilken i första hand inneburit att vi i stället för ett samlat kulturarv bör tala om många olika. Bönder, borgare, kvinnor, invandrare, ungdomar och många andra grupper har försetts med egna kulturarv, liksom industrisamhället och förintelsen.

Nedmonteringen av drömmen om ett gemensamt och samlande nationellt kulturarv har stora analytiska poänger. Utan tvekan är det en illusion att tro att människor delar villkor och kulturella uttryck, såväl i det förgångna som i vår egen samtid. Samtidigt är det viktigt att påpeka att hur museimännen avväger mellan det mångfacetterade och det entydiga till stor del hänger samman med vilket perspektiv de väljer för att betrakta de företeelser de arbetar med. Det är de som väljer såväl vilken historia som ska berättas, som sättet att framföra den på.

\section{MUSEERNAS KULTURPOLITISKA PRAKTIK}

Varje samhälle har behov av ett offentligt samtal om sin historia och kultur - även när den inte är lockande för stora besöksgrupper och därmed "lönsam" (se Ames 1992). Det finns emellertid en fara i det post-moderna antagandet att var och en är sin egen auktoritet precis som i idén om att kunden alltid har rätt. Museerna behöver markera ett avstånd från "marknaden" - dvs. besöksstatistiken den vet inte alltid bäst. Medborgarna är mer än bara konsumenter och kultur är mer än bara en vara. Vad som är värdefullt kan inte alltid avgöras i opinionsmätningar.

När jag valt att studera kulturarvets institutioner genom den praktik de bedriver, är det just för att undersöka hur de på en gång artikulerar en godkänd narration - och producerar 
ett övermått av betydelser. Mer och mer framstår de som samlingar av iscensatta och gestaltade tecken, som blivit allt mer åtråvärda i takt med att det förgångnas konjunkturer stigit. I takt med att den ifrågasättande och dekonstruerande trenden fått fotfäste bland museimännen presenterar allt färre utställningar entydiga tolkningar för besökarna. Detta innebär att kulturarvsinstitutionerna kommer att fungera som reservoarer av rekvisita och betydelser snarare än att utgöra absoluta sanningsinstanser ens i egna ögon. Tecknen, föremålen, narrationerna kan brukas alltefter person och sammanhang (se t.ex. Alzén \& Hedrén 1998, Bohman \& Palmqvist 1997, Hooper-Greenhill 1992, Kaplan 1994). Samtidigt åstadkoms detta just genom att museerna presenterar väl dokumenterade berättelser om det enskilda och konkreta. Men berättandet om det särskilda blir, som Paul Ricoeur (1991) visat, både en modell av människors erfarenheter av tiden och en modell för hur de kan uppleva den. Det är i denna dubbla funktion museerna blir reservoarer för besökarnas egna meningsskapanden snarare än vägvisare i historisk förståelse.

Om vi vill se museerna som emancipatoriska blir just funktionen att bistå i människors eget meningsskapande en viktig uppgift, som kan ge en grund för socialt handlande. Men i det sammanhanget är den post-moderna relativismen, eller ansvarsöverlåtelsen, knappast en effektiv strategi. Under de senaste två decennierna har sådana kulturkonstruktivistiska idéer och synsätt vuxit sig starka inte minst genom att problematisera tidigare för-givet-tagna "realistiska" perspektiv inom humanistisk och samhällsvetenskaplig forskning. I dag är sådana konstruktivistiska idéer väl etablerade och kan sägas tillhöra den uppsättning av vetenskapliga förutsättningar, som själva behöver utmanas (se t.ex. Lash 1999). För museerna kan problemet sägas ligga i att om vi anammar idéerna om museet som konsumtions- eller kundorienterat, relativiserande och dekonstruerande ställs vi bara inför nya frågor: I en kör av många röster, där varje röst anses vara lika mycket värd som en annan, vad händer där med det vetenskapliga talet? Hur blir handlande, socialt agerande och frigörelse möjligt i ett sådant samhälle?

Som reservoar för meningsskapande och grund för handlande behöver utställningar vara konkreta på ett sätt som bryter med att vara rena illustrationer av rådande diskurser. ${ }^{16}$ Att helt enkelt illustrera diskusen om att krig är hemska, även om det görs på ett tekniskt utmärkt sätt, lyckas inte bryta den distansering och o-medvetenhet vi har till denna typ av övergripande föreställningar, nästan lika lite som ett alltför abstrakt friläggande av diskursen kring skånska bönder lyckades göra det. Det konkreta blir representationer, utställningarna blir representationsanalyser och mänskliga handlingar blir vaga och ogripbara diskurser (jfr Siikala 2000). Det vi försökte göra i Helsingborg misslyckades primärt därför att vi inte lyckades beröra besökarna. Det vi försökte säga grep inte tag i deras egna erfarenheter och framstod därför som både obegripligt och ointressant. $\mathrm{Vi}$ lyckades inte återknyta det avklippta bandet över tidsspannet. Armémuseums utställningar fungerar kanske främst när de lyckas skapa små öppningar in i historien som vi kan förhålla oss till. Utställningen lyckas när den ger oss en känsla av dåtidens levda verklighet. Talet om trettioåriga kriget och de förmögenheter vissa kunde bygga på sitt deltagande är vagt och abstrakt $\mathrm{i}$ jämförelse med det påtagliga $\mathrm{i}$ ärren från syfilisen. Utan att kunna värja mig, tänkte jag rätt åt honom där jag stod framför instal- 
72 lationen - och även om det kanske inte var just en sådan reaktion utställningsmakarna hade eftersträvat, uppstod här något nytt i mötet mellan kulturarv och nutida, vardagligt liv (jfr Stewart 1996).

Det är tydligt för var och en att en utställning är en utsaga om verkligheten, inte ett utsnitt av verkligheten själv. Men den är en utsaga om verkligheten som uppträder inom citationstecken. Därmed utgör utställningen en arena där besökaren kan reflektera och distansera sig från sin egen vardag, och utställningen kan öppna en väg som gör det möjligt att överskrida det redan kända. Som fenomen är detta naturligtvis inget nytt, men genom att ställa den analytiska frågan om vad en utställning gör med besökarna, på en existentiell snarare än en publikundersökande nivå, kan kanske även den museala praktiken bryta ut av den representationsanalytiska tvångströjan.

\section{NOTER}

1. När jag började inse at utställningens budskap var långt ifrån självklart, startade jag "spionera" på de fătaliga besökarna för att försöka förstå vad det var som gått snett.

2. Åtminstone sedan den stora utredningen MUS 68 (se Rentzhog 1996), har museerna gärna kallat sig sambällets minne. Detta är en benämning - eller magisk formel - som etablerades som en egenskapsangivande karaktäristik med den stora museiutredningen Minne och Bildning från 1995 (SOU 1994: 51) och som starkt understryker museets roll som realistisk tidsatergivare.

3. På en mer praktisk nivå kan man naturligtvis tänka sig många orsaker till detta sammanbrott, t.ex. att vi var för otydliga i vårt sätt att presentera budskapet. Här är jag emellertid framför allt intresse- rad av de mer principiella slutsatser som kan dras av utställningens öde.

4. 1996, antog riksdagen nya kulturpolitiska mål, som ersatte 1974 års mål (prop. 1996/97:1, bet. 1996/97: KrU1, rskr. 1996/97:129). Som det femte av de totalt sju målen finns målet "att bevara och bruka kulturarvet".

5. Benämningen museiman används här som en könsneutral yrkesbenämning: personer med akademisk utbildning som arbetar vid ett museum.

6. Ett liknande resonemang, om än i ett helt annat sammanhang, har övertygande framförts av den norska etnologen Connie Reksten Kapstad i hennes avhandling (Reksten Kapstad 2002).

7. I en ofta refererad men nästan mytisk undersökning p.g.a. sin brist på referens, hävdas att upprepade publikundersökningar visat att museibesökare framför allt uppskattar tre saker: ett bra fik, en spännande butik och rena toaletter.

8. Den andra halvan av det andra våningsplanet upptas av en omfattande vapenutställning mängder av vapen prydligt placerade i glasmontrar, värd att uppmärksammas av inga andra än de specialintresserade.

9. Efter den svenska generalen Armfeldts misslyckade försök på att besätta Trondheim 1718 frös flera tusen svenska soldater ihjäl på fjället under återtåget till Jämtland.

10. Det enda storskaliga krig jag kan se entydigt hyllas som rättvist och gott är kriget mot nazismen under 1939-45.

11. Kevin Hetherington (1999) har fört en diskussion kring museernas utveckling som fokuserar just på hur "blicken" förenar besökare och föremål. I korthet går hans argumentation ut på att det moderna museet utvecklades under 1800-talet $i$ en anda av "the Kantian gaze of the connoisseur". Med detta avses att den mångfald som föremålen i själva verket utgjorde nedtonades genom att underordnas utställningens narrativa struktur och budskap. Museernas berättelser gav besökarna rol- 
len av att känna igen och uppskatta skönheten i framsteget/civilisationen/nationen (Hetherington 1999: 66ff).

12. Genomslaget i denna tes är fullt synligt i dagens Museisverige, inte minst i den nyorientering som skett på Historiska museet.

13. Det är naturligtvis annorlunda med ledda gruppbesök, där museipedagogen aktivt kan skapa tillfällen till samtal.

14. Resonemanget kring dokumentarisk och gestaltande historia har tidigare utvecklats i Hansen (2001).

15. Den amerikanske antropologen Arjun Appadurai förklarar skillnaden så här: “... history leads you outward, to link patterns of changes to increasingly larger universes of interaction, genealogy leads you inward, toward cultural dispositions and styles that might be stubbornly embedded both in local institutions and in the history of the local habitus" (Appadurai 1997 (1990): 74).

16. Med diskurs avses här en helhet av sammanhängande påståenden, yttranden och begrepp om någonting., som styr hur vi uppfattar och talar om verkligheten.

\section{LITTERATUR}

Alzén, Annika \& Johan Hedrén: Kulturarvets natur. Stehag \& Stockholm: Symposion. 1998.

Ames, M.: Cannibal Tours \& Glass Boxes: The anthropology of Museums. Berkely: University of California Press 1992.

Appadurai, Arjun 1997: "Consumption, Duration, and History". I Appadurai, Arjun: Modernity at Large. Cultural Dimensions of Globalization. Minneapolis: University of Minneapolis Press 1997 (1990).

Armémuseum. Informationsbroschyr. U.å.
Bennett, Tony: The Birth of the Museum. History,

Bohman, Stefan: "Besökarna och museendet av historien" in Bohman, Stefan \& Lennart Palmqvist: Museer och kulturarv. Stockholm: Carlssons Bokförlag 1997 (a).

Bohman, Stefan: "Vad är museivetenskap och vad är kulturarv. in: Bohman, Stefan \& Lennart Palmqvist: Kulturarv och museer. Stockholm: Carlssons Bokförlag 1997 (b).

Bohman, Stefan \& Lennart Palmqvist: Museer och kulturarv. Stockholm: Carlssons Bokförlag 1997.

Cameron, Duncan: "The Museum: A Temple or the Forum”. Journal of World History. Volume 14. No. 1. 1972.

Frykman, Jonas: "National Identity: Between Modernity and Cultural Nationalism". Festchfrit für Konrad Köstlin. Wien 2000.

Hansen, Kjell: "Att skapa förgången verklighet". Kulturens årsbok 2001.

Hein, George E.: "Evaluating teaching and learning in museums" in Hooper-Greenhill, Eilean (ed.): Museum, Media, Message. London \& New York: Routledge 1999.

Hetherington, Kevin: "From Blindness to blindness: Museums, Heterogenity and the Subject" in Law, John and Hassard, John: Actor Network Theory and After. (s 51-71) Oxford: Blackwell Publishers 1999.

Hobsbawm, E.: "Introduction: Inventing traditions" in E. Hobsbawm \& T. Ranger (eds): The invention of tradition. Cambridge: Cambridge University Press 1983, s. 1-14.

Hooper-Greenhill, Eilean: "The museum in the Disciplinary Society" in Pearce, S. (ed): Museum Studies in Material culture. Leicester: Leicester University Press 1989.

Hooper-Greenhill, Eilean: Museums and the Shaping of Knowledge. London: Routledge 1992.

Hooper-Greenhill, Eilean: "Audiences - A Curatorial Dilemma" in Pearce, Susan (ed.): Art in Mu- 
seums. New Research in Museum Studies. London: Athlone Press 1995.

Hylland Eriksen, Thomas: Historia, myt och identitet. Stockholm: Bonniers 1996.

Kaplan, Flora (ed): Museums and the Making of "Ourselves". The Role of Objects in National Identity. London \& New York: Routledge 1994.

Karlsson, Sten O.: "När Sverige fick sin historia tillbaka" in Alzén, Annika \& Johan Hedrén: Kulturarvets natur. Stehag \& Stockholm: Symposion 1998.

Kirschenblatt-Gimblett, Barbara: Destination Culture: Tourism, Museums, and Heritage. Berkeley: University of California Press 1998.

Klein, Barbro: "Tillhörighet och utanförskap. Om kulturarvspolitik och folklivsforskning i en multietnisk värld”. Rig, 1-2. 1997.

Lash, Scott: Another Modernity, a Different Rationality. Oxford: Blackwell Publishers 1999.

Leech, P.: "Heritage and national identity in contemporary Britain” (1997) in M. Mäkikall, Korhonen, A, \& Virtanen, K. (eds): European identities studies on integration, identity and nationhood. Publications of the doctoral program on cultural interaction and integration. Volume 2. Lindeborg 1991.

Reksten Kapstd, Connie: Nar handling tar plass. Ein kulturstudie av Fellesaksjonen mot Gasskraftverk. Doktorsavhandling. IKK, Universitetet i Bergen 2002.

Rentzhog, Sten 1996: 70-talets museum - 25 år efter. Nordisk Museologi. Nr. 1. 1996, s. 23-30.

Ricoeur, Paul: "The Human Experience of Time and Narrative" in Valdés, Mario J. (ed): A Ricoeur Reader: Reflection and Imagination. Toronto and Buffalo: University of Toronto Press 1991.

Shotter, J.: Cultural Politics of Everyday Life. Milton Keynes: Open University Press 1993.

Siikala, Anna-Leena: "From Sacrificial Rituals into National Festivals: Post-Soviet Transformations of Udmurt Tradition" in Anttonen, Perrti et al (eds.): Folklore, Heritage Politics and Ethnic Diversity. A Festschrift for Barbro Klein. Botkyrka: Mångkulturellt centrum 2000.

Silvén-Garnert, Eva: "Samtidsforskning som ett förhållningssätt" in Bohman, Stefan \& Lennart Palmqvist (red): Museer och kulturarv. Stockholm: Carlssons Bokförlag 1997.

Silvén, Eva: "Svåra saker och farliga berättelser. Representation, etik, makt och politik i museer och kulturarv" in Rogan, Bjarne \& Bente Gullveig Alver (red.): Norden og Europa. Fagtradisjoner i nordisk etnologi og folkloristikk. Oslo: Novus forlag 2000.

SOU. Nr 51.1994: Minne och bildning. Museernas uppdrag och organisation. Slutbetänkande av $\mathrm{Mu}$ seiutredningen. Stockholm: Kulturdepartementet.

SOU. Nr. 18. 1999: Industrisambällets kulturarv. Slutbetänkande. Stockholm: Kulturdepartementet.

Stewart, Kathleen: A Space on the Side of the Road. Cultural Poetics in an "Other" America. Princeton: Princeton University Press 1996.

Stoklund, Bjarne: "International exhibitions and the new museum concept in the latter half of the $\mathrm{Ni}$ neteenth century". Ethnologia Scandinavica. 1993.

Stoklund, Bjarne: "Idén om ett friluftsmuseum". Kulturens årsbok 2001.

\section{SUMMARY}

Using the author's personal experience of an unsuccessful exhibition as a starting point, this paper discusses the way museums act as mediators of knowledge. While museum officials have accepted post-modern influences of de-constructivist perspectives, museum visitors tend to regard exhibitions as realistic traces of the past, and exhibitions that question ideas of 
the past we take for granted are thus often unable to communicate effectively with visitors.

A number of researchers have claimed that museums not only present, but also create, cultural heritages because they possess the right to interpret what objects and other phenomena should be part of an exhibition. Museums thus mould particular images of the past. This de-constructivist knowledge seems to have established uncertainty among curators, who have left the idea of one common (national) heritage, and instead have started arguing for a number of different heritages connected to different groups in society. This may all be very well, but at the same time many museums have problems in communicating with visitors.

In order to analyse this, it may be worthwhile to see exhibitions as occurrences - i.e. as actions taking place when visitors meet the concrete exhibition as it stands. Using the Swedish Army Museum as an empirical reference, it is argued that the meanings of cultural heritages are not fixed, and that a heritage is not something that has been lost and found again. Heritage is dependent on being presented, and thus creates something new in the present while at the same time referring to the past.

But since museum officials tend to define themselves as gatekeepers of correct details, rather than as narrators of comprehensive stories, there tends to evolve a gap between what the exhibition is saying, and the lived experiences of the visitors. If we see the real world as something that is not given once and for all, we can also see how museums partake of the social and cultural construction of reality. Exhibitions contribute to producing ideas about how the world is constituted. But among many of those who presently work in museums, there is a sense of discomfort attached to the role as teller of staged stories, of stories that go beyond the simple factuality of the specific and concrete. Instead, they would like to see themselves as suppliers of a material which the visitors may use as they please. Museum exhibitions thus, on the one hand articulate approved narratives, and on the other produce an excess of meaning. They appear as collections of staged and directed signs that have become all the more desirable as the past has become more popular, as reservoirs of props and meanings rather than as institutions of truth.

It is obvious to anyone that exhibitions are statements about reality rather than a piece of reality itself. But it is a statement that appears within quotation marks and thus is - or could be - an arena for reflection, when it is able to reach the visitor's experiences across the gap of time.

Kjell Hansen, FD, etnolog och museolog. Arbetar f.n. som forskare vid Etnologiska institutionen, Lunds universitet, men har bred erfarenhet frän svenska museer, samt som lektor i museologi.

E-mail: kjell.hansen@etn.lu.se 